
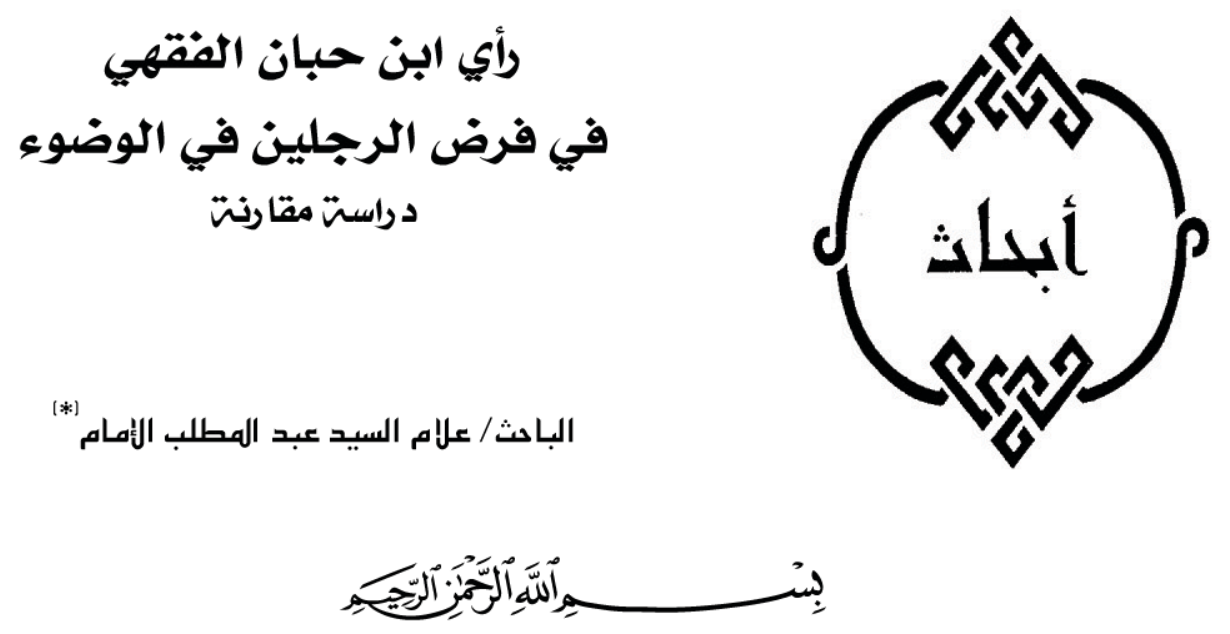

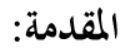

الحمدد لله رب العالمين، وأشهد أن لا إله إلا الله ولي الصالحين، وأشهد أن محمـــاً عبده ورسوله صلى الله عليه وعلى آله وصحبه أجمعين. أما بعد:

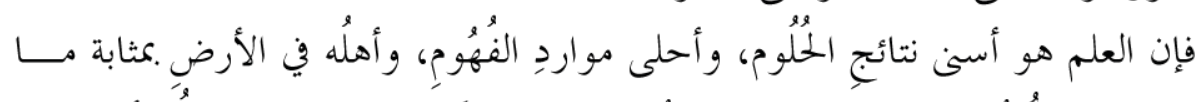

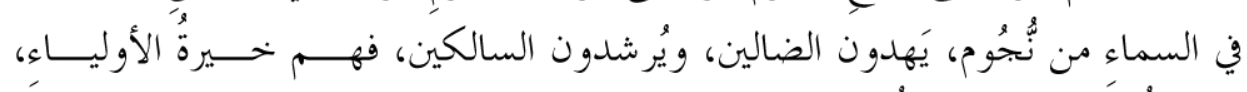

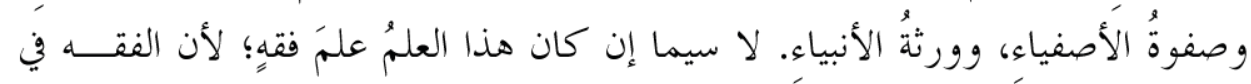

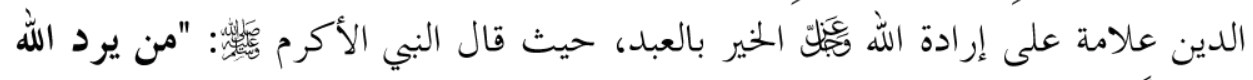

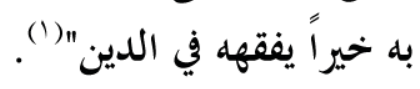
(") جامعة كفر الشيخ - كلية الآداب - قسم اللغة العربية و آدابها.

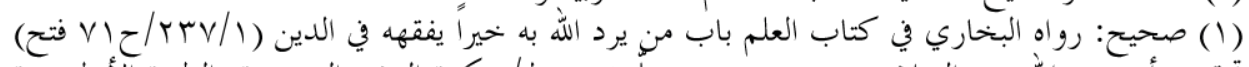

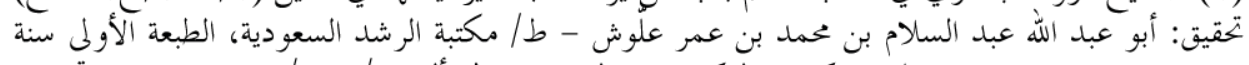

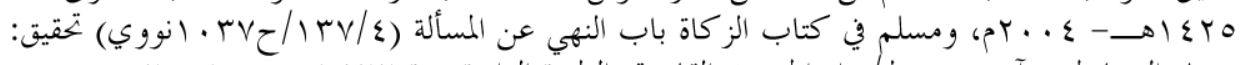

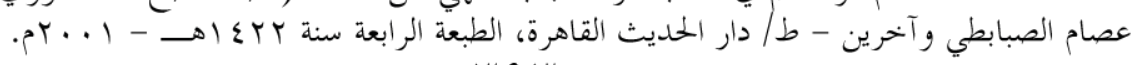
-rqu. 


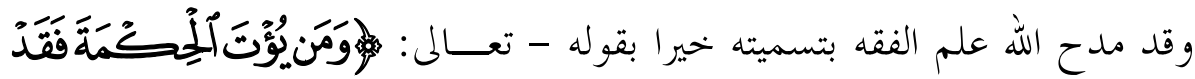

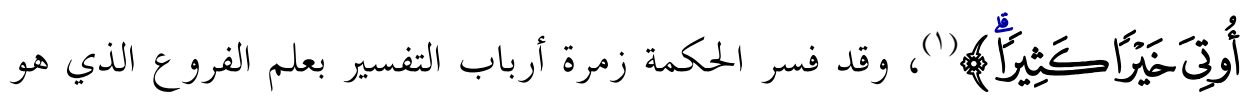

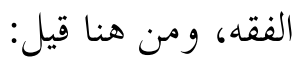

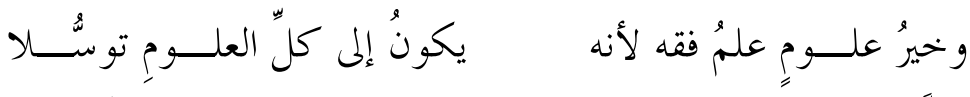

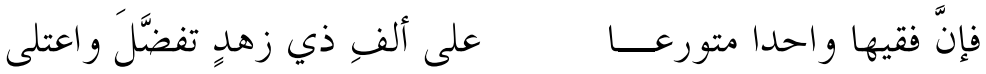

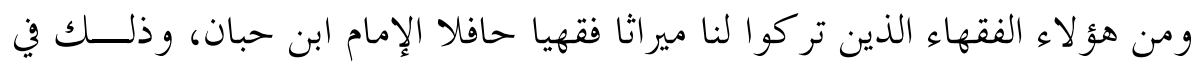

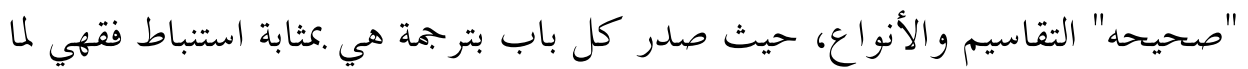

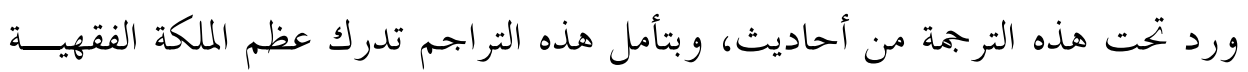

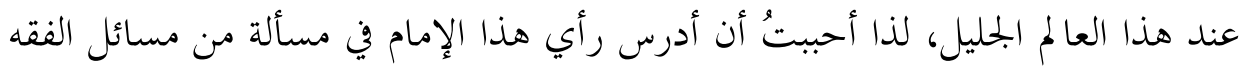

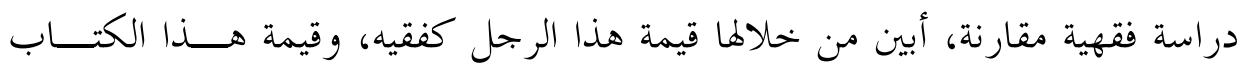

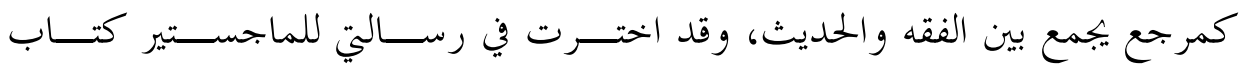

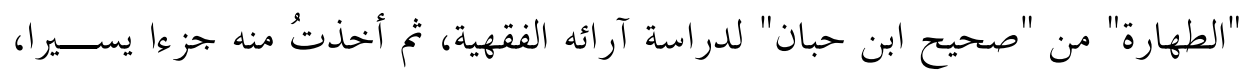

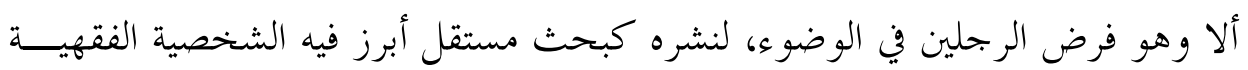

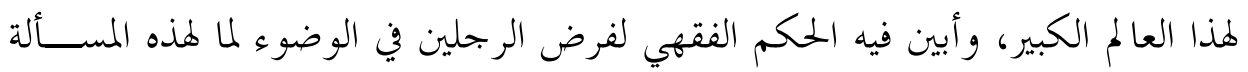

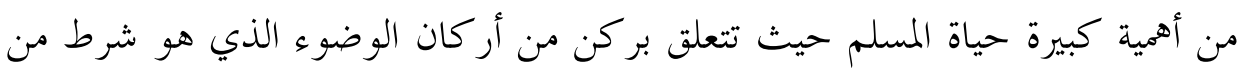

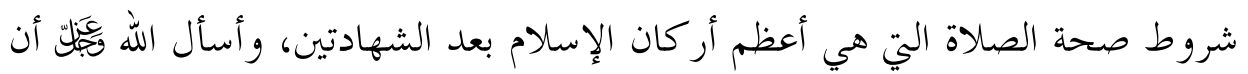

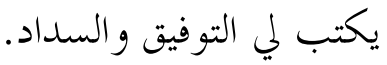

(1) سورة البقرة: جزءء من الآية (Y79). 


\section{هدف الدراسة:}

\section{تمدف هذه الدراسة إلى عدة أمور أهمها ما يلي:}

1- إبراز شخصية الإمام ابن حبان الفقهية، من خلال التراجم التي ذكرها في صحيحه

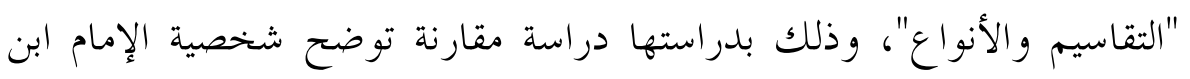
حبان وما يتمتع به من ملكة فقهية تمكنه من استنباط الأحكام من حديث رسول

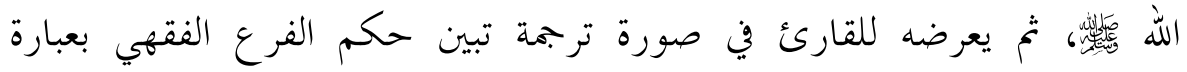

$$
\text { موجزة. }
$$

ץ- عرض آراء الفقهاء في كل مسألة يتعرض ها الإمام ابن حبان، وبيان مدى المو افقة

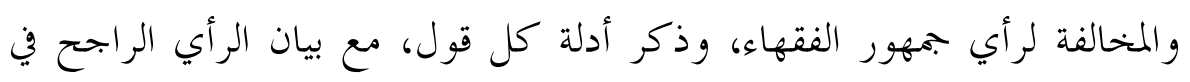
كل مسألة. r- إظهار كتاب الإمام ابن حبان في صورة جديدة، ككتاب من كتب الفقه، تختلف عن صورته المعهودة ككتاب حديث.

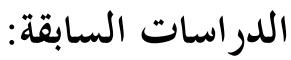

لم أقف على أعمال سابقة في موضوع البحث إلا على رسالة ماجستير في المكتبة المركزية بجامعة الأزهر بعنوان: "آراء الإمام ابن حبان الأصولية في صحيحه" وهي إني كما هو واضح من عنواها تختلف في موضوعها عن رسالتي، حيث إنها تبحث الآراء

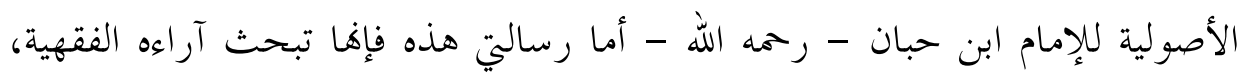
فالفرق بينهما واضح لكل ذي عينين لا يحتاج إلى بيان أو توضيح. 
وقد قسمتُ هذا البحث إلى مقدمة، ومطلبين، وخاتمة. أما المقدمة: فقد بينت فيها أهمية الفقه في الدين، وأشرت إلى أهمية كتاب ابن حبان ككتاب يجمع بين الحديث و الفقه، كما تحدثت عن الدراسات السابقة، وذكرتُ فيها

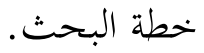

والمطلب الأول: في رأي ابن حبان في هذه المسألة. والمطلب الثاني: في آراء الفقهاء في هذه المسألة. والحاتمة: ذكرتُ فيها أهم النتائج وأهم التوصيات. *** 


\section{المطلب الأول \\ رأي ابن حبان في هذه المسألت}

يمكن معرفة رأي الإمام ابن حبان في هذه المسألة من خلال التراجم التي ذكرهــا،

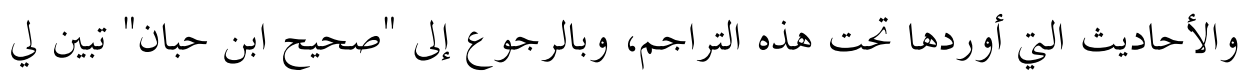

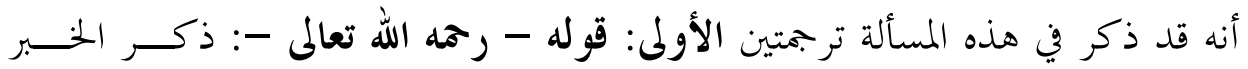
المدحض قول من زعم أن الفرض على المتوضئ في وضوئه المسح على الــرجلين دون

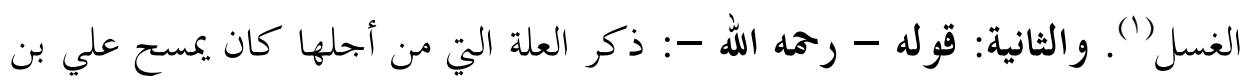

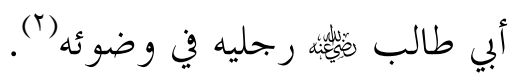

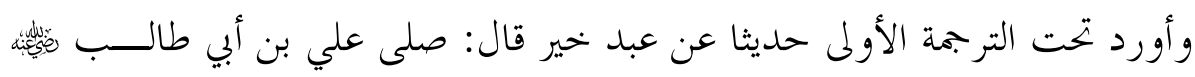

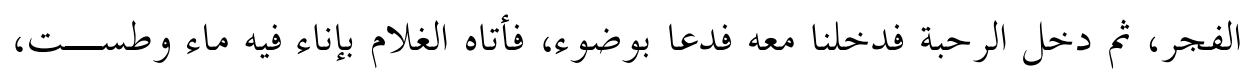

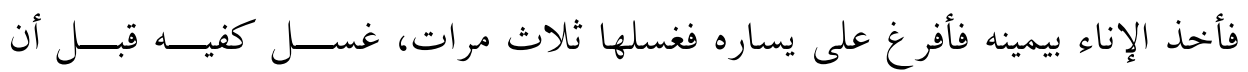

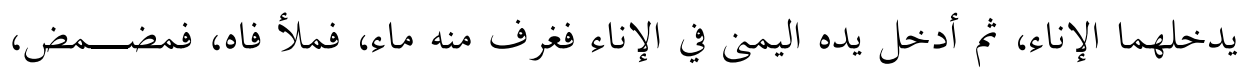

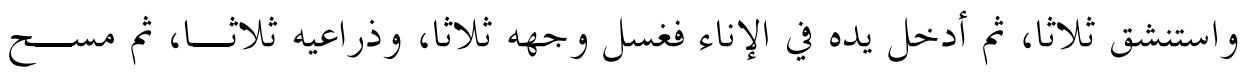
رأسه بيديه جميعا: مقدمه ومؤخره، ثم أدخل اليمنى فأفرغ على قدمه اليمنى فغسلها، ثم

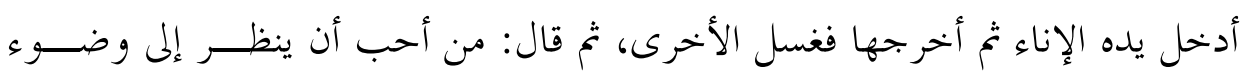

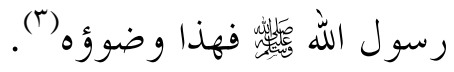

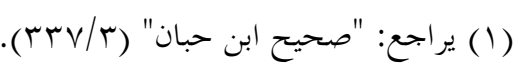

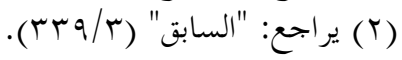

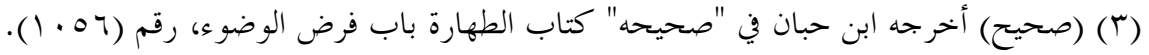

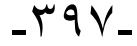


وأورد تحت الترجمة الثانية حديثا عن النـــزال بن سبرة قال: صليت مع علي بن أبي طالب نِّئن: الظهر تمح انطلق إلى بحلس له كان يجلسه في الرحبة، فقعد وقعدنا حوله حتى

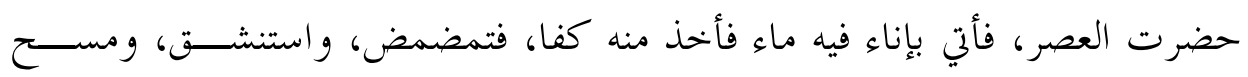
و جهه وذراعيه، ومسح برأسه، ومسحح رجليه، ثم قام، فشرب فضل إنائه، ثم قال: إين

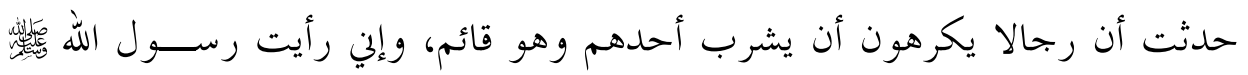
فعل كما فعلت وهذا وضوء من لم يحدث (1).

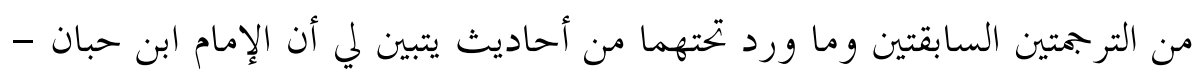

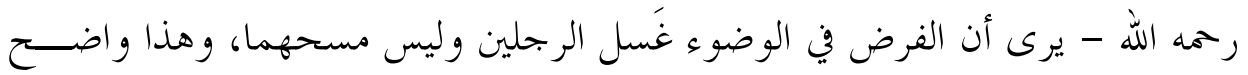

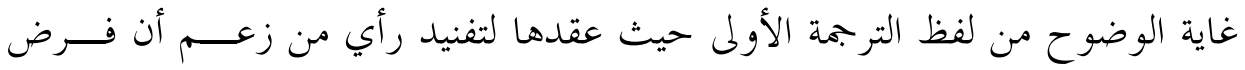

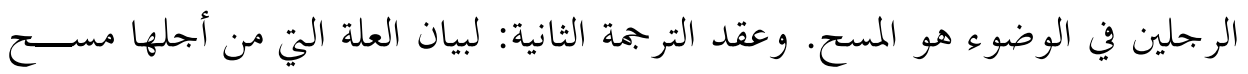

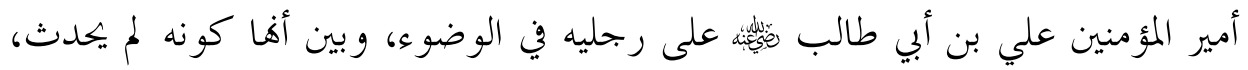

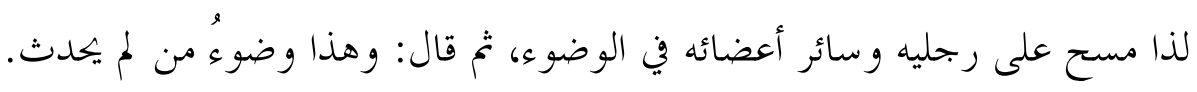

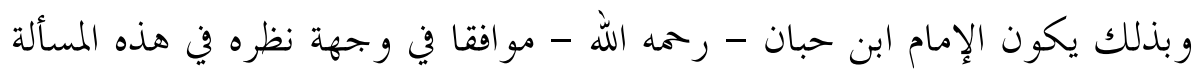
لرأي جمهور الفقهاء على ما سيأتي بيانه قريبا إن شاء الله تعالى. *** $*$

$$
\text { (1) (صحيح) أخرجه ابن حبان في "صحيحه" كتاب الطهارة باب فرض الوضوء، رقم (1) ـ ـ (1). }
$$




\section{المطلب الثاني \\ آراء الثقهاء في هذه المسألنت المهاتي}

اختلف الفقهاء في هذه المسألة على ثلاثة أقوال، وقبل بياها ينبغي أن أحرر محــل النــزاع، وأبين سبب الخلاف فأقول:

تحرير محل النــزاع: اتفق الفقهاء على أن الرجلين من أعضاء الوضوء، و لا خلاف بينهم في هذا، و اختلفوا في نوع طهارقما هل هي طهارة مسح أم غسل؟ على ثلاثـــــ أقوال (1) (2)

سبب الحخلاف في هذه المسألة: يرجع اختلاف الفقهاء في هذه المسألة إلى أن الآية قرئت بقراءتين: بالنصب و الحفضض، فمن قال بالمسح أخذ بقراءة الخفض، فإنها تقتضي كون الأرجل ممسوحة لا مغسولة؛ لأها تكون معطوفة على الرأس، و المعطوف يشارك المعطوف عليه في الحكم، ثم وظيفة الرأس المسح فكذا وظيفة الرجل، ومصداق هـــــهـ القراءة أنه اجتمع في الكلام عاملان: أحدهما: قوله تعالى: (فاغسلوا)، والثاني: حرف الجر وهو الباء في قوله تعالى: (برؤوسكم)، و الباء أقرب فكان الحفض أولى. ومن قال بالتخيير يقول إن القراءتين قد ثبت كون كل واحدة منهما قر آنا، وتعذر برون الجمع بين موجبيهما، وهو وجوب المستح و الغسل إذ لا قائل به في الســلف، فــيخير

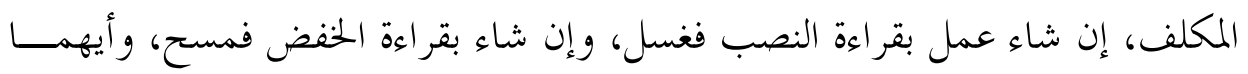

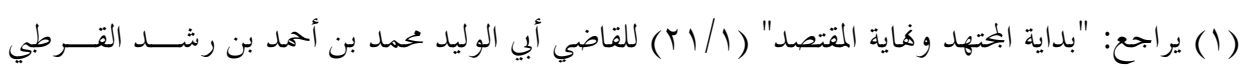

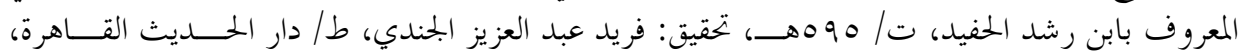

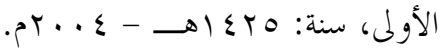


فعل يكون إتيانا بالمفروض. ومن قال بالجمع يقول: القراءتان في آية واحدة بمنــــــلة

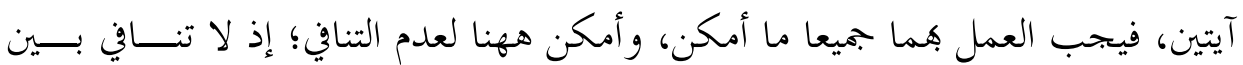
الغسل والمسح في محل واحد فيجب الجمع بينهما' (1).

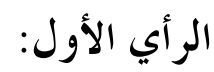

أن فرض الرجلين في الوضوء الغسل وليس المسح، روي هذاعن عمر، وعلــي (r)،

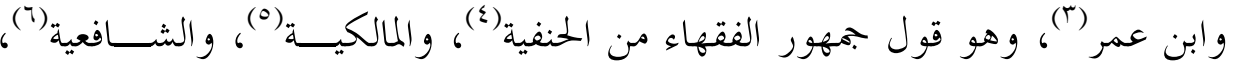

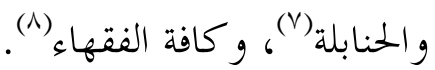

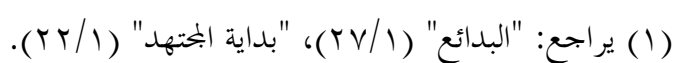

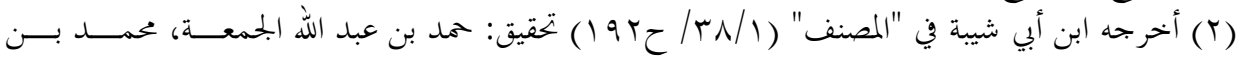

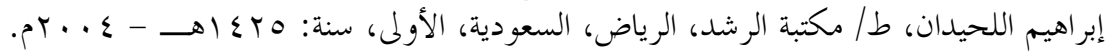

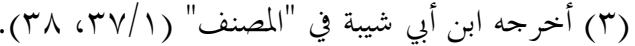

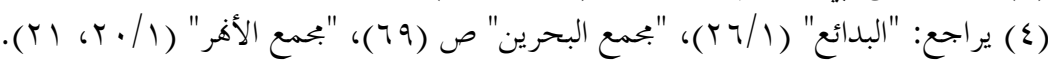

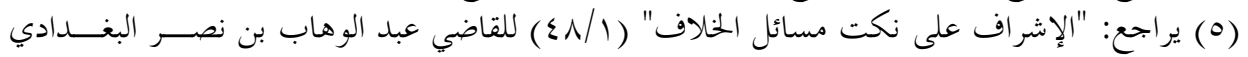

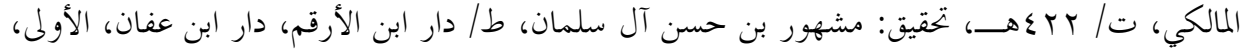

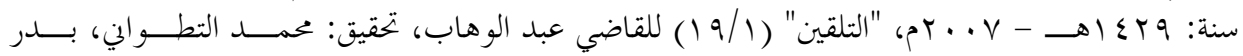

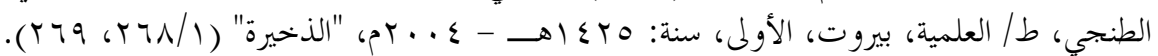

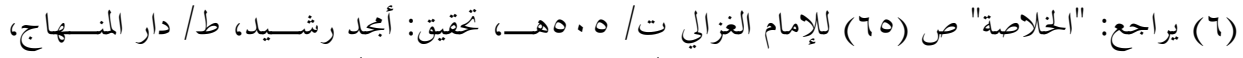

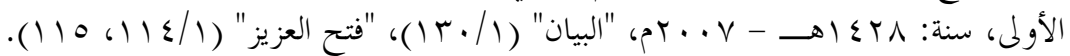

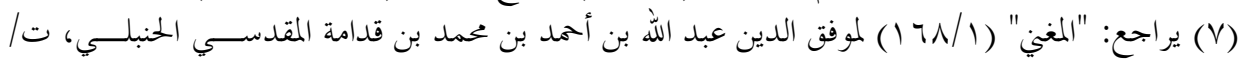

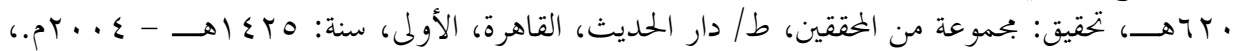

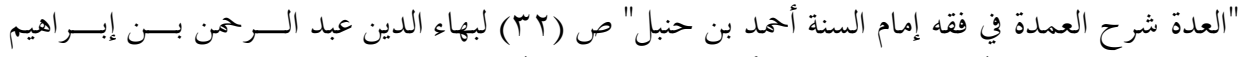

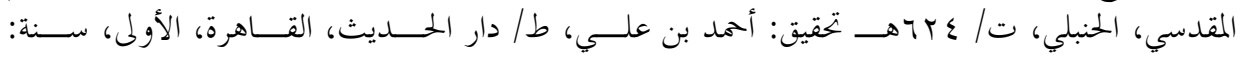

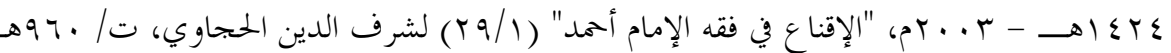

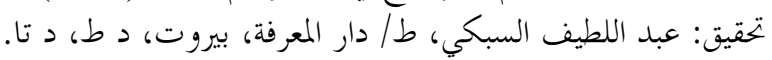

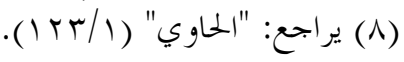




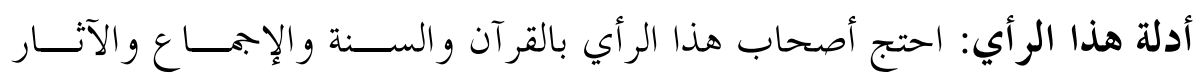
و القياس:

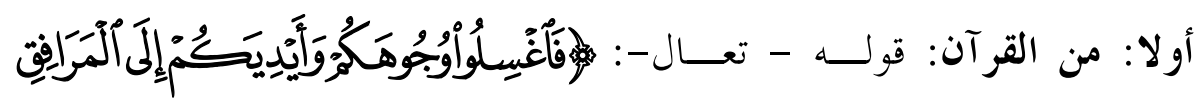

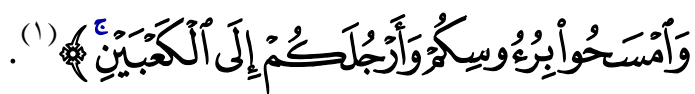
وجه الدلالة: أن كلمة "أرجلكم" في هذه الآية منصوبة على أحد وجهين: الأول:

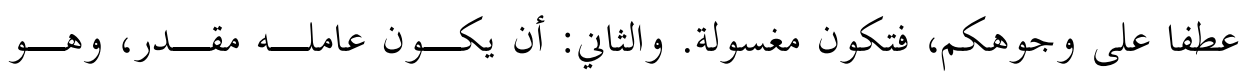
(و اغسلوا) كما تقول: أكلت الحبز واللبن. أي: وشربت اللبن، وإن لم يتقدم للشرب ذكر، وهنا تقدم للغسل ذكر فكان أولى (r). ونوقش: بأنه إن كانت هذه القراءة المنصوبة تدل على الغسل، فالقراءة المخفوضة تدل على المسح، فلا تقدم إحداهما على الأخرى (r).

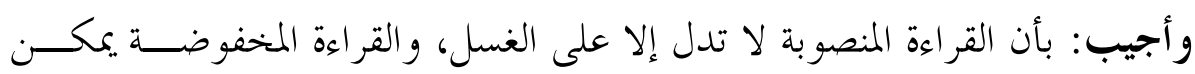
حملها على أحد وجهين: أحدهما: على مسح الخفين فيكون اختلاف القراءتين علــى اختلاف المعنيين. و الثاني: أنه محمول على العطف على اللفظ دون المعنى(ع). ثانيا: من السنة: جملة من الأحاديث، منها:

(1) سورة المائدة: جزء من الآية (T).

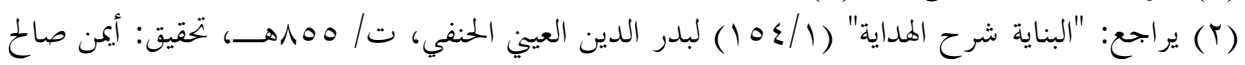

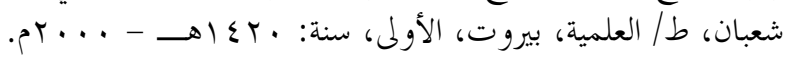

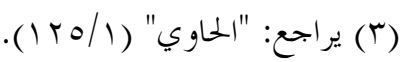

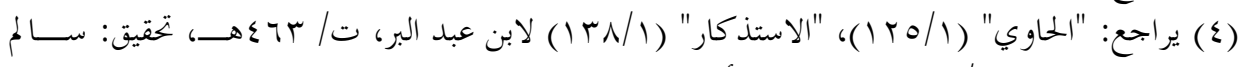

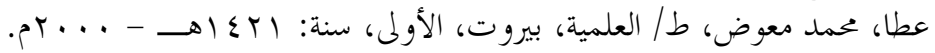




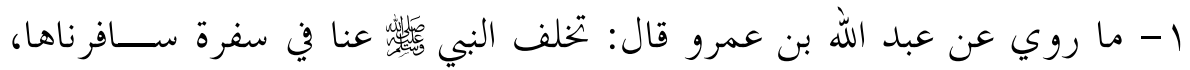
فأدر كنا وقد أرهقنا العصر، فجعلنا نتوضأ ونمسح على أرجلنا، فنادى بأعلى صـــــه: "ويل" للأعقاب من النار" مرتين أو ثلاثا" (1).

r- ما روي عن أم المؤمنين عائشة - رضي الله عنها - أن عبد الرحمن بن أبي بكر لـان

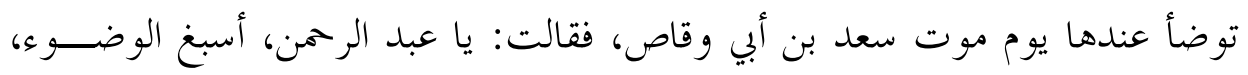

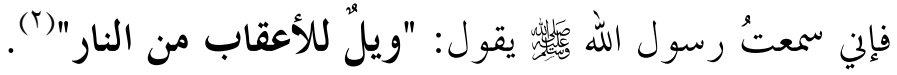

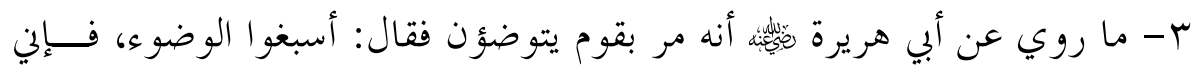

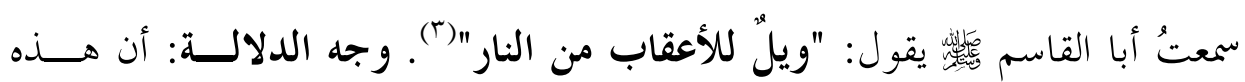

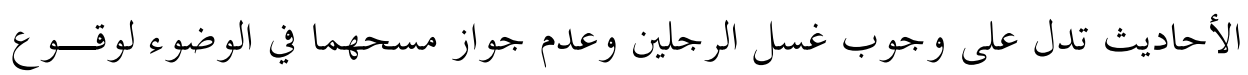
الوعيد الشديد فيهما على من تركك بعض رجله لم يصل إليه الماءع (ع).

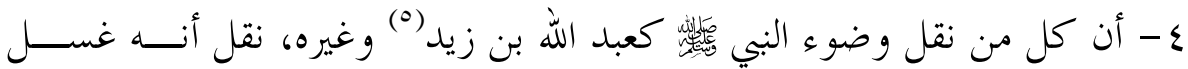
رجليه (T)

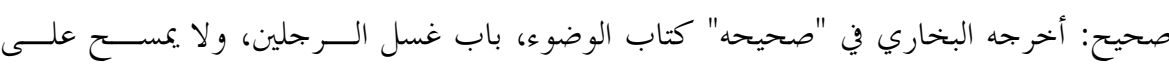

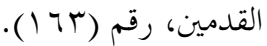

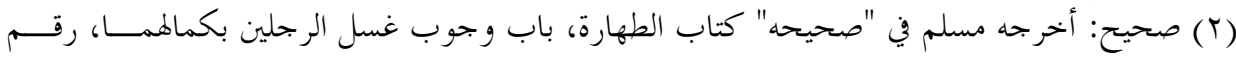

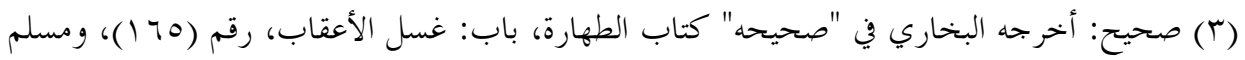

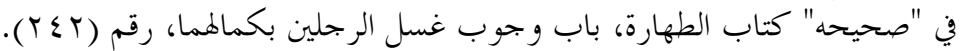

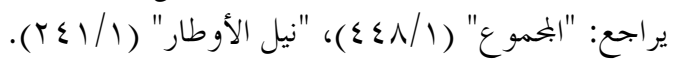

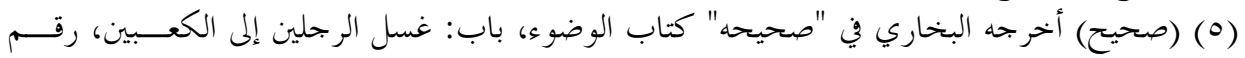

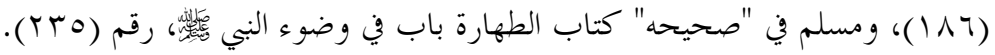

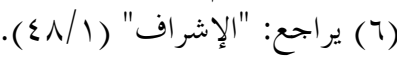




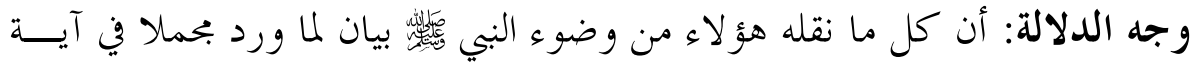

$$
\text { الوضوء؛ فدل على أنه الواجب( '). }
$$

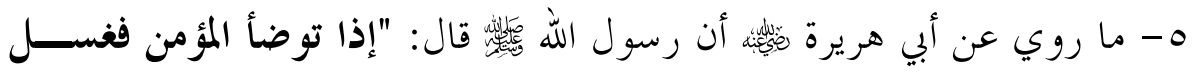

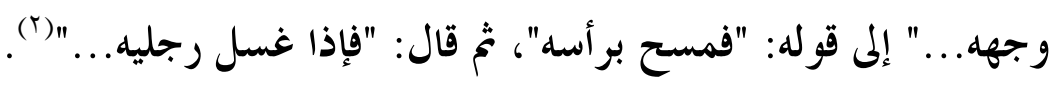

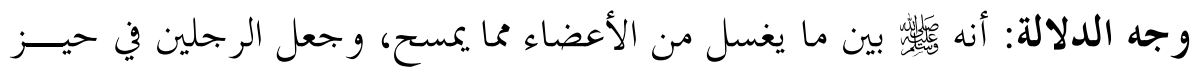

$$
\text { ما يغسل، فدل على أن ذلك فرضهما (َ). }
$$

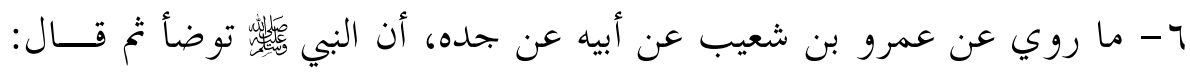

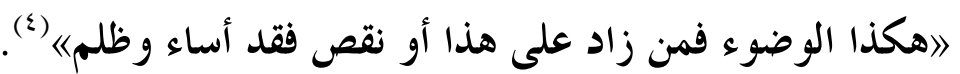

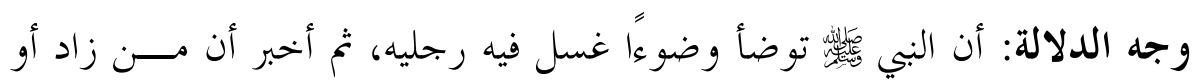

نقص فقد أساء وظلم، و لا شك أن المسح بالنسبة إلى الغسل نقص (ْ).

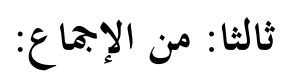

قال الإمام النووي: "اختلف الناس فيها على مذاهب، فذهب جميع الفقهاء من أهل

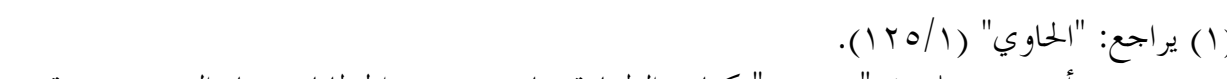

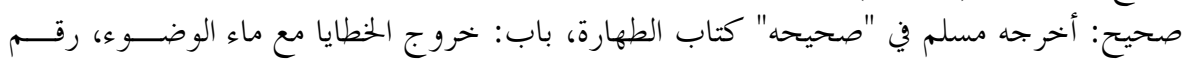

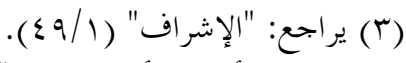

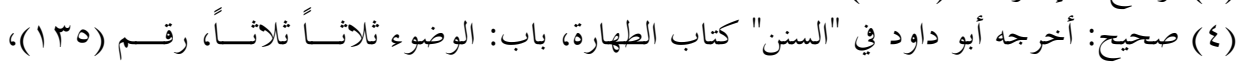

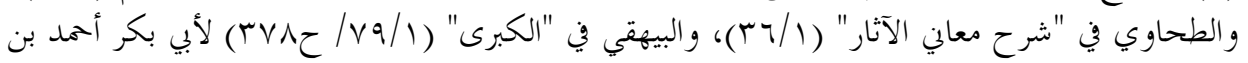

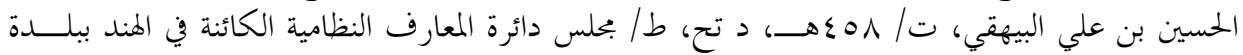

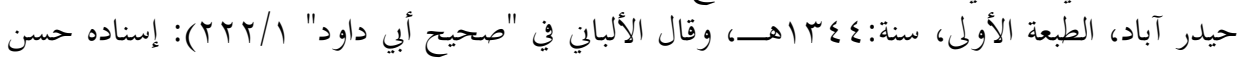

$$
\text { صحيح. }
$$


الفتوى في الأعصار والأمصار إلى أن الواجب غسل القدمين مع الكعبين، ولا يجــزئ مسحهما، ولا يجب المستح مع الغسل، و لمم يثبت خلاف هذا عن أحدٍ يعتــد بــهـ في

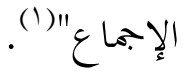

قال الحافظ ابن حجر: و لم يثبت عن أحد من الصحابة خلاف ذلك، إلا عن علي، و ابن عباس، وأنس، وقد ثبت عنهم الرجوع عن ذلك(r). وقال الإمام الشو كاني: قال

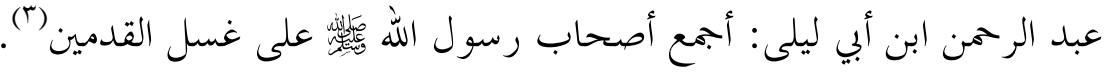
قال الحافظ ابن عبدالهادي: "ومفروض إجماعًا غسل رجليه إلى الكعبين" (ع).

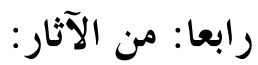

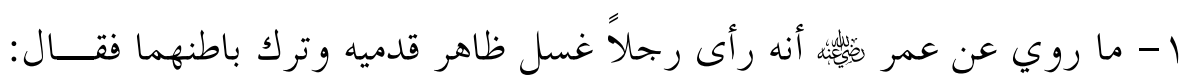

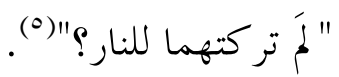

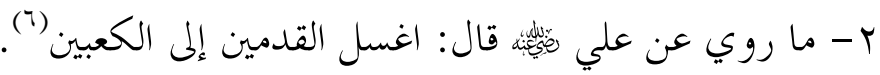
ب- ما روي عن بحاهد عن ابن عمر قال: إن كنت لأسكب عليه المـــاء فيغســل

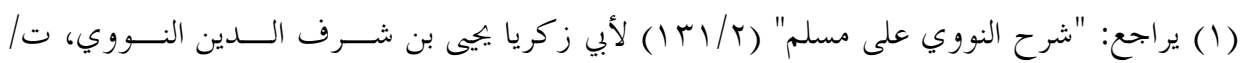

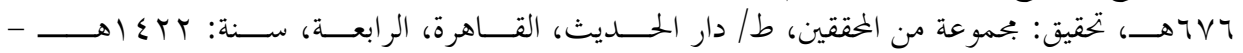

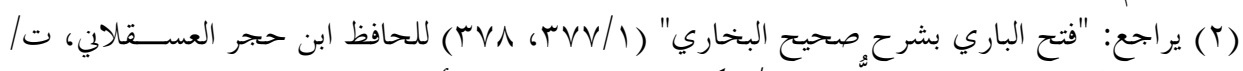

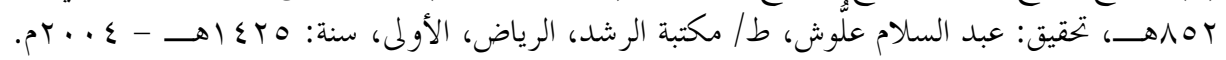

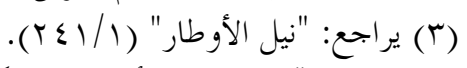

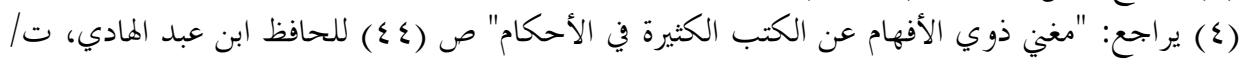

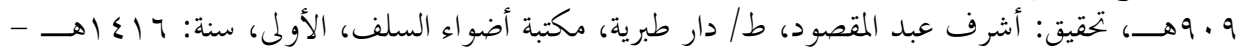




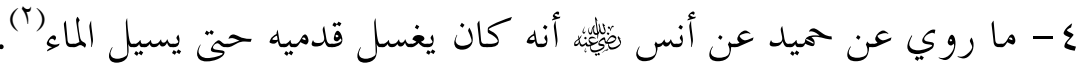

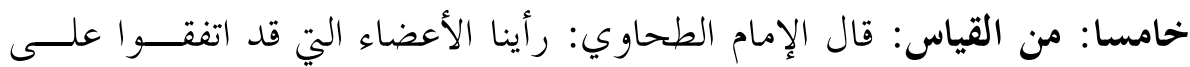

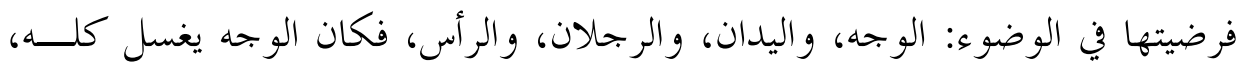

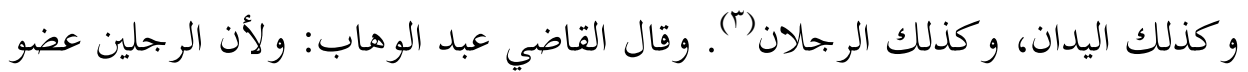

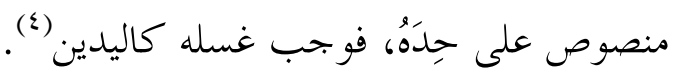

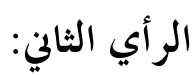

أن فرض الرجلين في الوضوء المسح، وليس الغسل، روي هذا عن علي بن أبي طالب، وابن

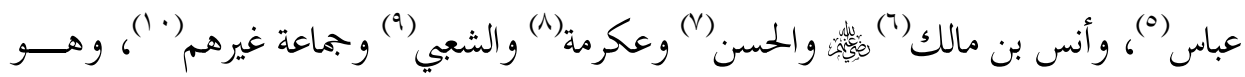

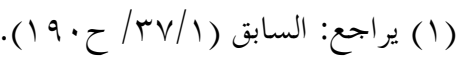

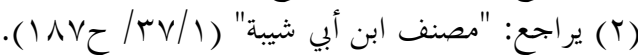

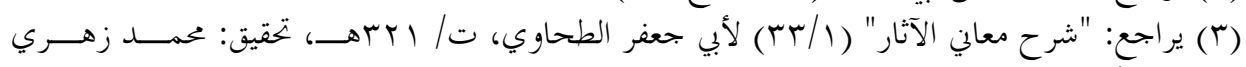

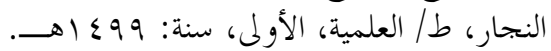

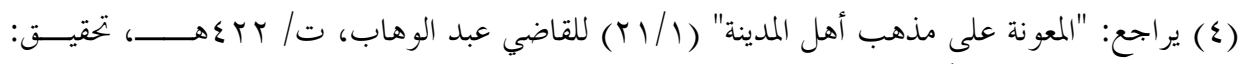

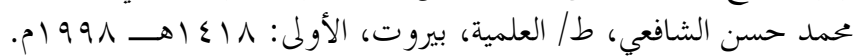

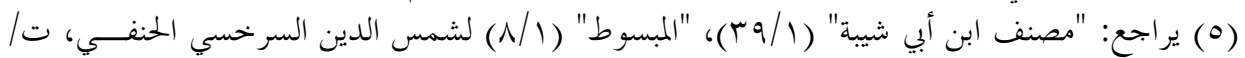

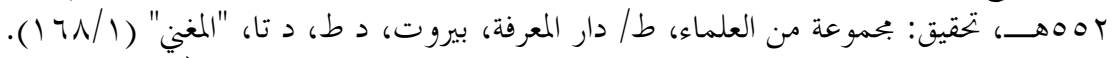

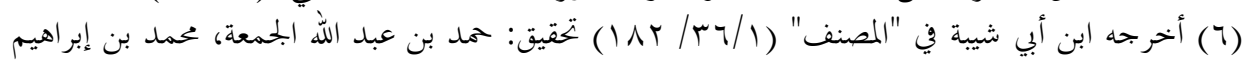

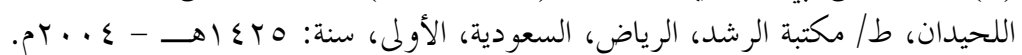

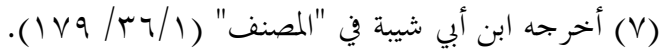

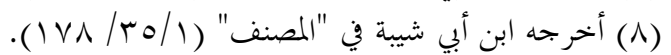

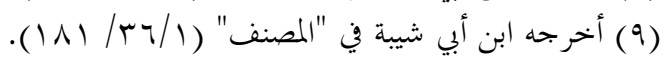


مذهب الشيعة الإمامية(')، وقول ابن حزم الظاهري(؟).

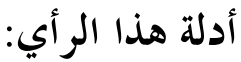
احتج أصحاب هذا الرأي بالقر آن و السنة والآثار و القياس: أولا : من القر آن: - من

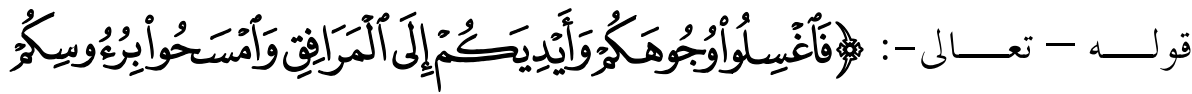

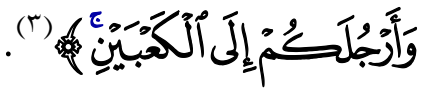
وجه الدلالة: قال ابن حزم: "القر آن نــزل بالمسح، وسواء قرى بخفض الــلام أو بفتحها، هي على كل حال عطف على الرؤوس، إما على اللفظ، أو على الموضع، لا يجوز غير ذلك؛ لأنه لا يجوز أن يحال بين المعطوف و المعطوف عليه بقضية مبتدأة(ع).

\section{ونوقش من و جوه: - من}

أحدها: بأهفا معطوفة عليها لفظا لا معنى، وهذا أمر معهود في كلام العرب، مثــل قول الشاعر : (20)

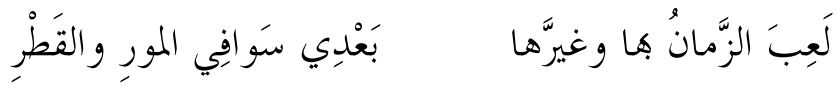

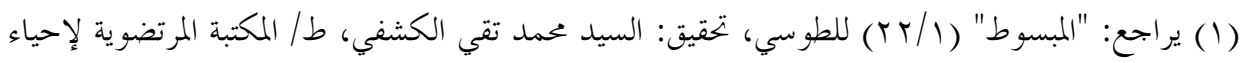

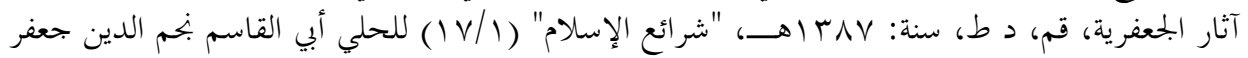

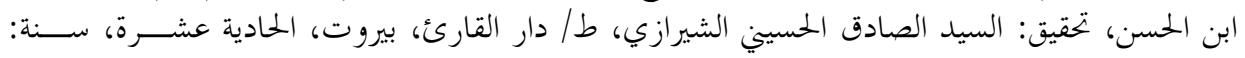

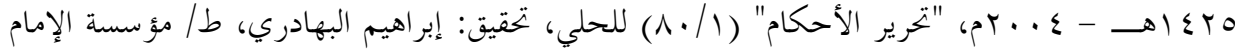

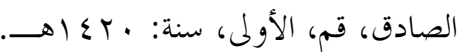

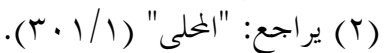

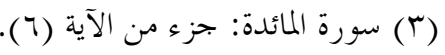

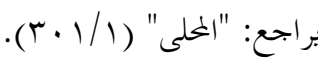




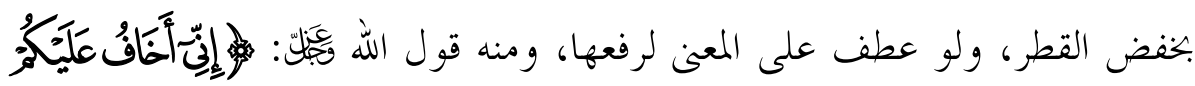

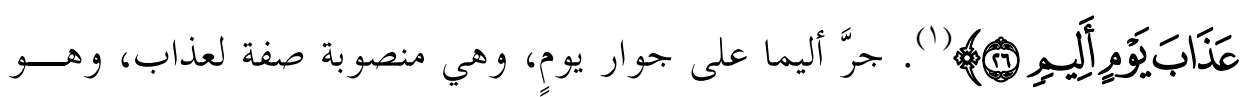

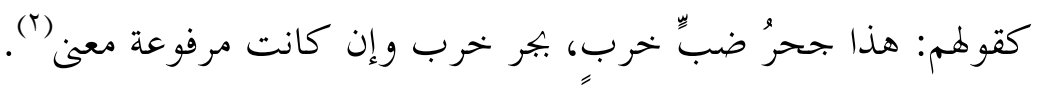

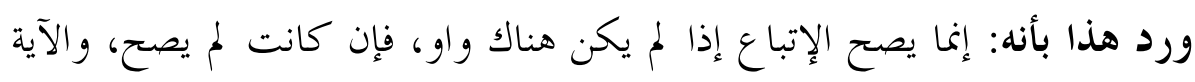
فيها واو. والجواب عن هذا الرد: بأن هذا غلط؛ فإن الإتباع مع الواو مشهورٌ في أشعارهم، ومنه قول الشاعر:

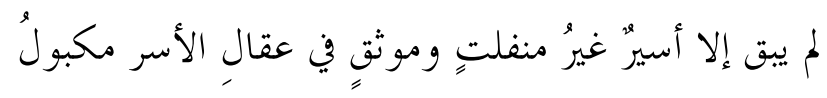

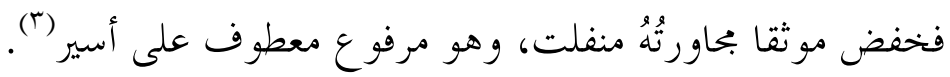

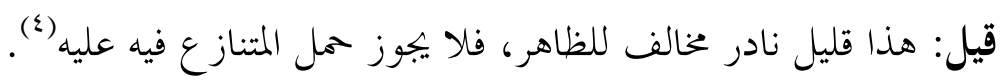

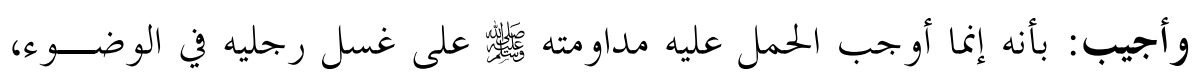

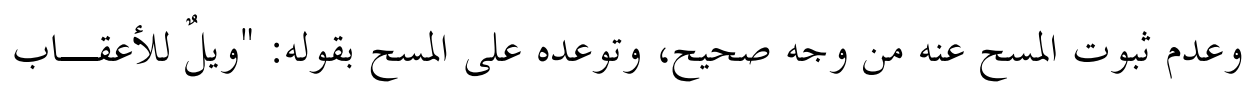

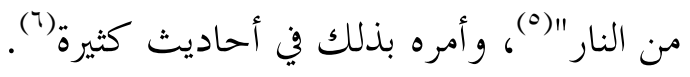

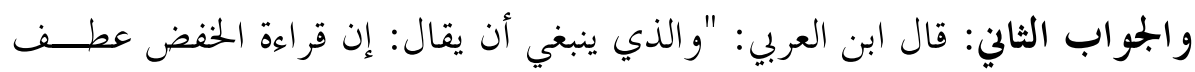

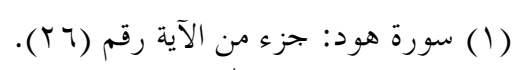

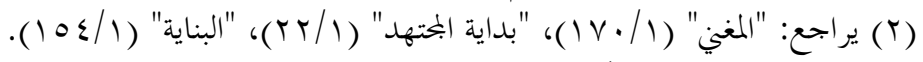

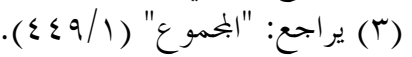

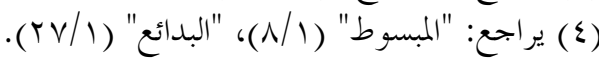

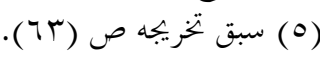

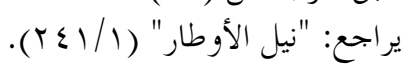


على الرأس، فهما يمسحان بكف إذا كان عليهما خفاف، وتلقينا هذا القيد من فعـل

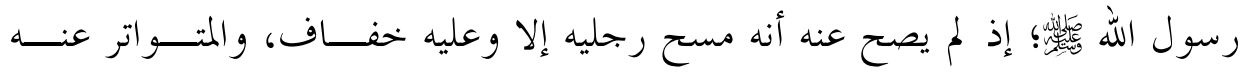

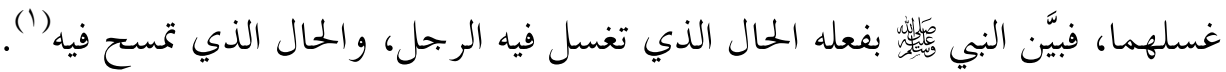

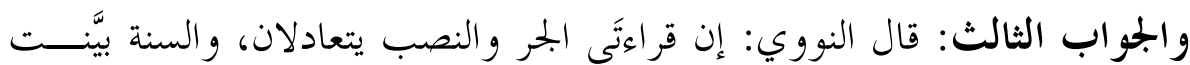

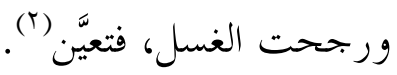

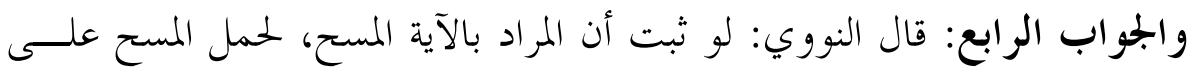

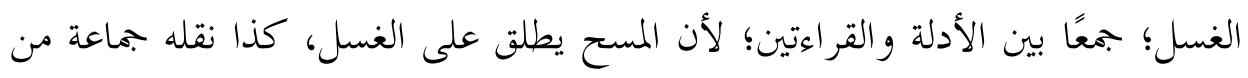

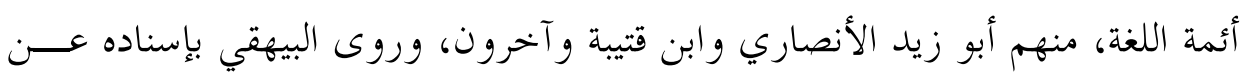

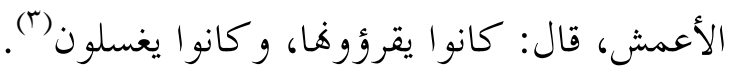

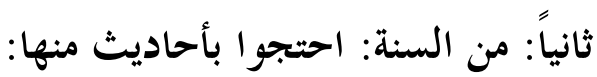

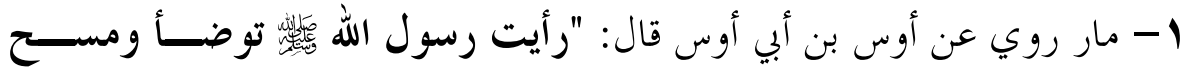
على نعليه وقدميه، ثم قام إلى الصلاة" (؟) .

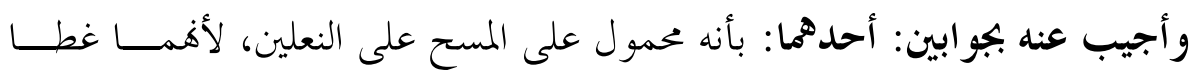

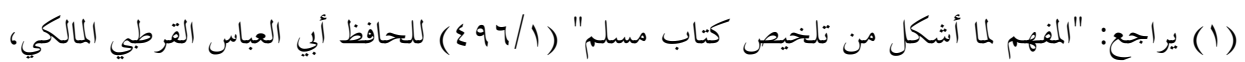

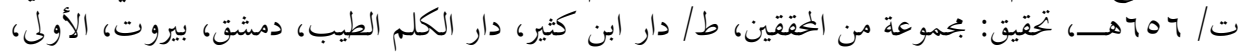
سنة:

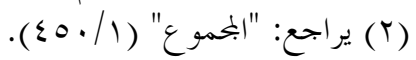

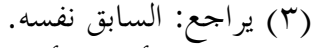

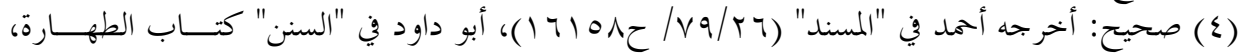

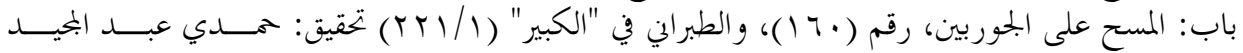

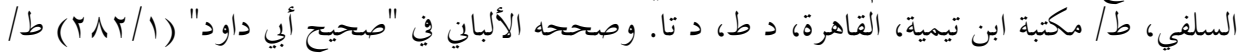

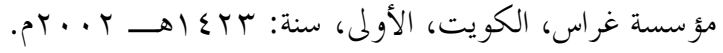


قدميه، فمسح عليهما كما مسح على الخفين (1) والجو اب الثالي: أن هذا كان في أول الإسلام كما قال هُشيم الراوي عني عن يعلى بن

عاء

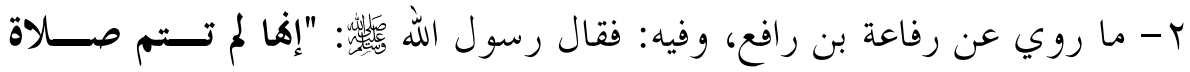

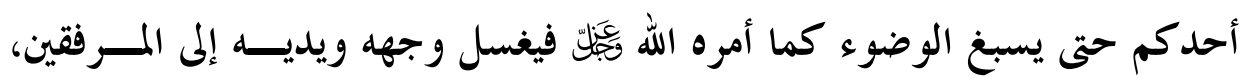
ويمسح برأسه ورجليه إلى الكعبين..." (")."

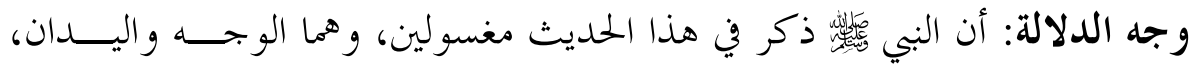
و ممسوحين، وهما الرأس والرجالان، فدل على أن الرجلين تمسحان في الوضوء (ع). ونوقش: بأنه على لفظ الآية، فيقال فيه ما قيل في الآية(ه).

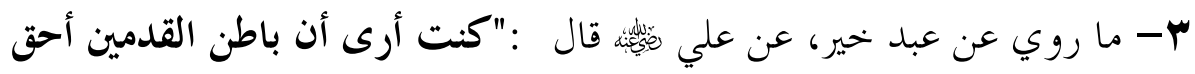

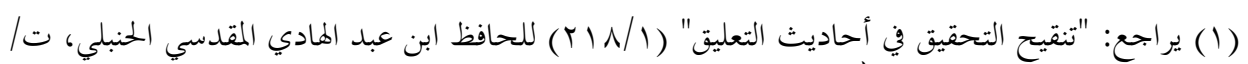

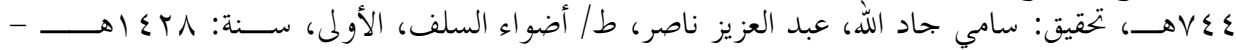

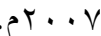

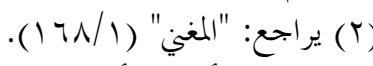

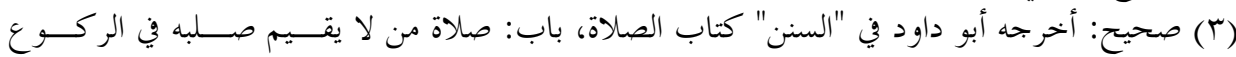

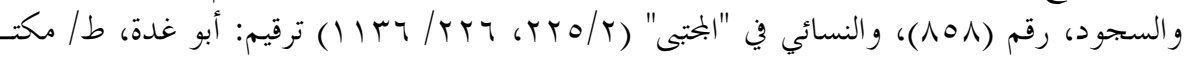

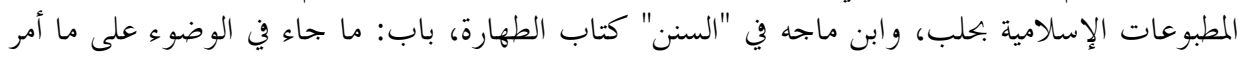

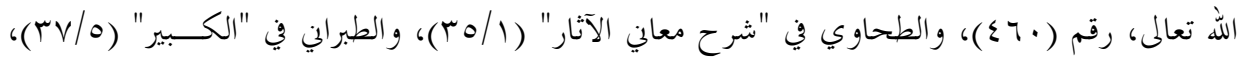

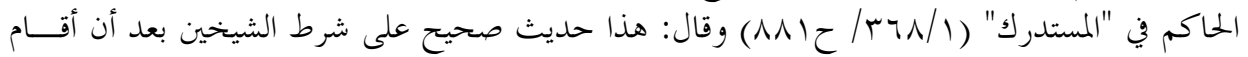

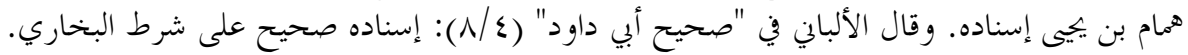

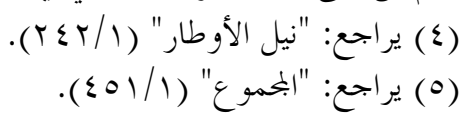




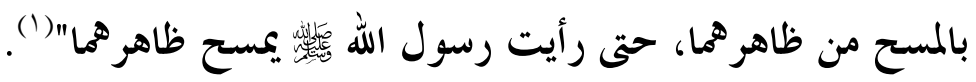
وجه الدلالة: أن قوله في الحديث: "يمسح على ظاهر هما" ظاهره أنه يمسح علــى

رجليه بدون خفين، وهذا دليل على أن فرض الرجل المسح دون الغسل (r).

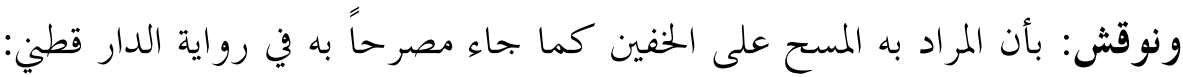
"كنت أرى أن باطن الحفين..." (؟).

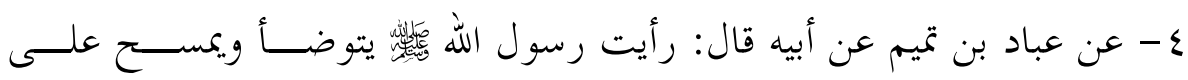
رجليه (๕)

وجه الدلالة: أن قوله: "ويمسح على رجليه" ظاهره أنه يمسح عليهما من غير خف ون

ونوقش: بقول الإمام الشوكاني: قال أبو عمر: في صحبة تميم هذا نظر، وضــفـ حديثه المذكور (7)

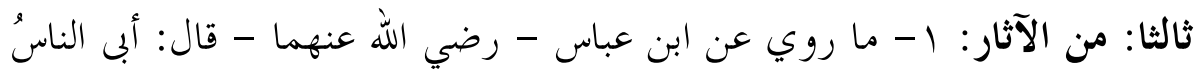

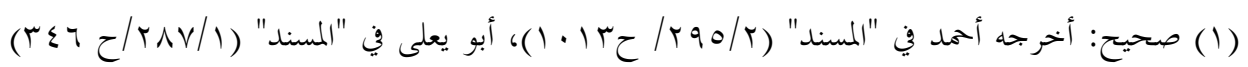

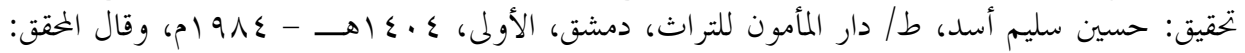

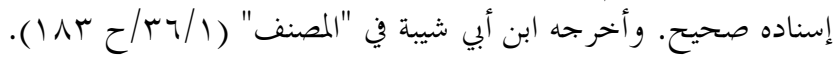

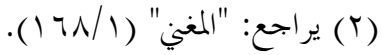

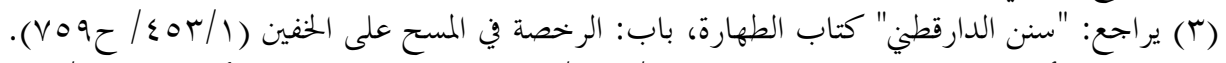

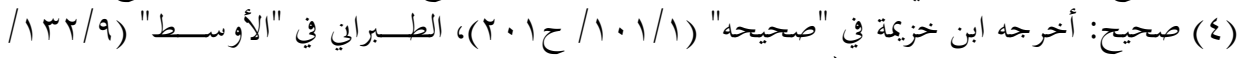

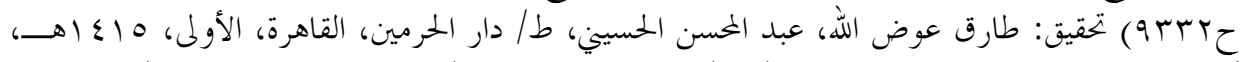

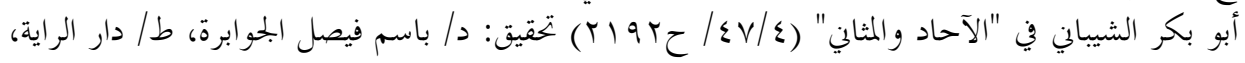

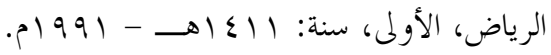

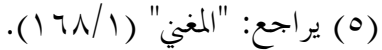

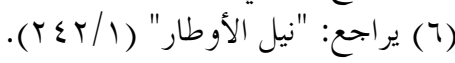


إلا الغسل، و لا أجد في كتاب الله إلا المسح (1).

ونوقش: بأنه قد ثبت عن ابن عباس الرجوع عن هذا القول إلى القول بوجوب

الغسل، فقد روى ابن أبي شيبة بسنده عن عكرمة عن ابن عباس أنه كان يقرأ:

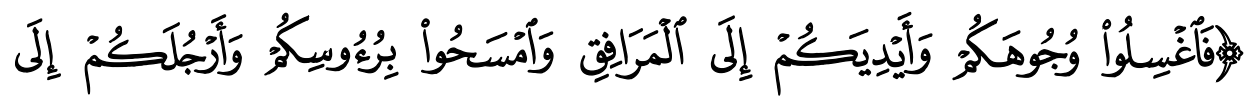

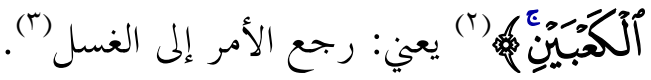

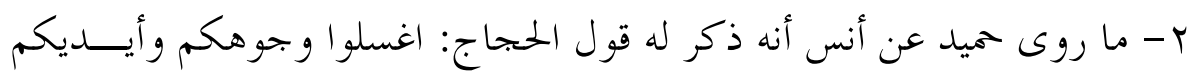
وأرجلكم فاغسلو ا ظاهرهما و باطنهما وعر اقيبهما، فإن ذلك أقرب إلى جنتكم. فتـــال

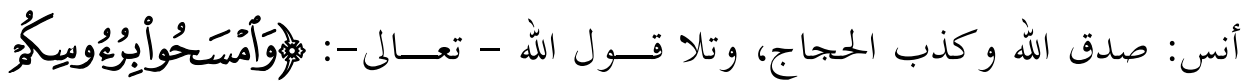

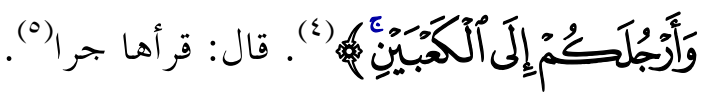

ونوقش بثلاثة وجوه: ذكرها النووي فقال: وأما الجواب عن احتجاجهم بكــلام

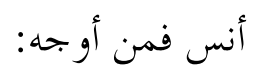

أشهرها: أن أنسا أنكر على الحهاج كون الآية تدل على تعيين الغســل، وكـــان يعتقد أن الغسل إنما علم وجوبه من بيان السنة، فهو موافق للحجاج في الغسل مخالف

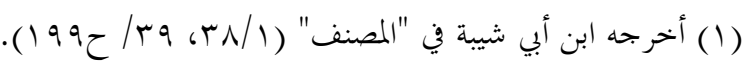

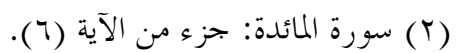

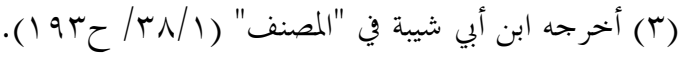

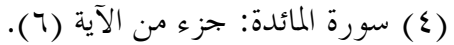

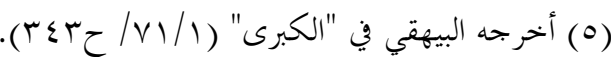

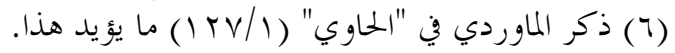

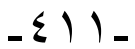


والثاني: أنه لم ينكر الغسل، إنما أنكر القراءة، فكأنه لم يكن يرى قراءة النصـــب،

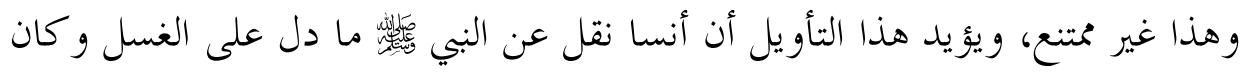
أنس يغسل رجليه.

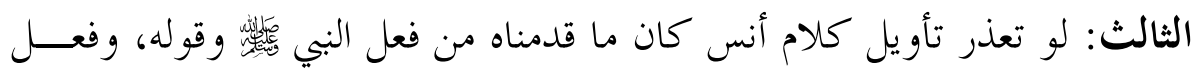
الصحابة وقولهم مقدما عليه (1).

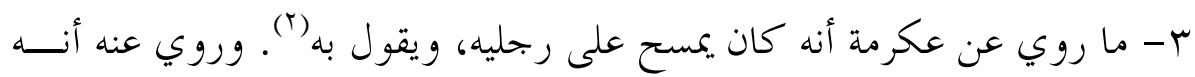
قال: غسلتان ومسحتان (r).

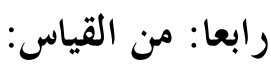
أنه عضو يسقط في التيمم، فكان فرضه المسح كالرأس (؛). ونوقش: بأن القيـاس

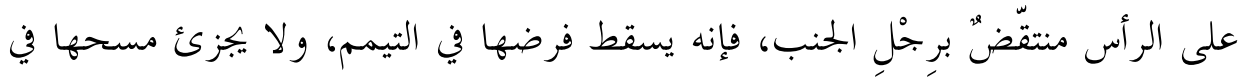
الغسل بالاتفاق (0).

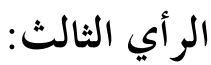

أن فرض الرجلين في الوضوء التخيير بين الغسل والمستح، فالمكلف مخــير بينـــما

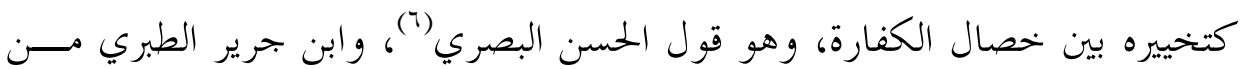

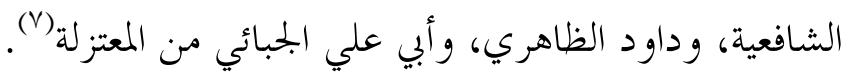

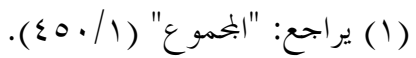

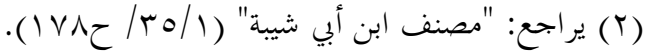

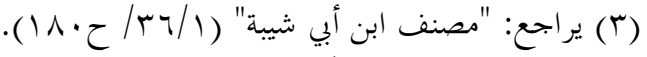

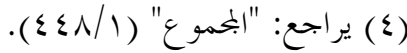

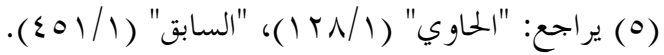

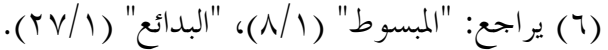

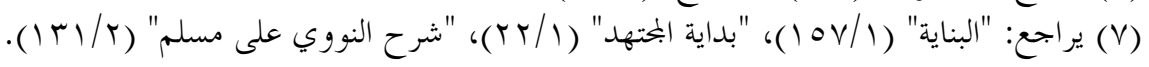

$$
\begin{aligned}
& \text { - } \varepsilon \mid Y_{-}
\end{aligned}
$$




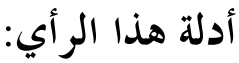

احتج أصحاب هذا الرأي على ما ذهبوا إليه .ما احتج به أصحاب القولين الأولين،

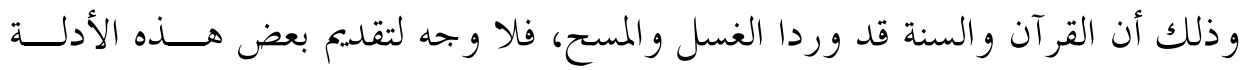

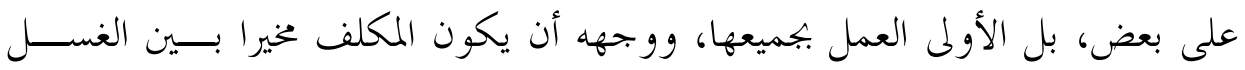
والمستح.

ونوقش هذا: بأنه ليس في الأدلة المتقدمة ذكر للتخيير، وليس فيها إشارة من قريب

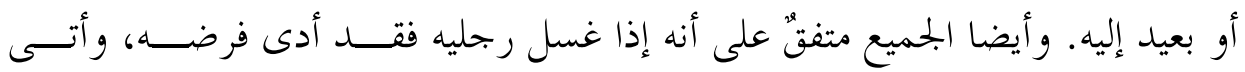

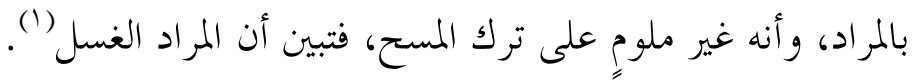

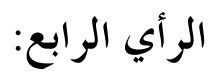

أن فرض الرجلين في الوضوء المسح والغسل جميعا، وهو قول بعض أهل الظاهر (ז).

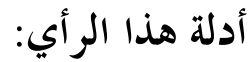

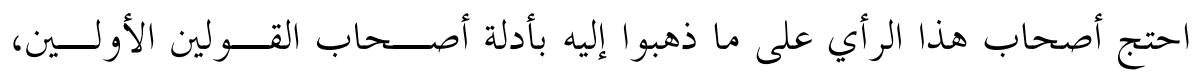

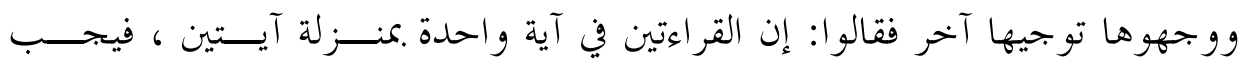

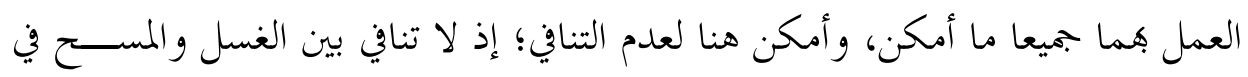

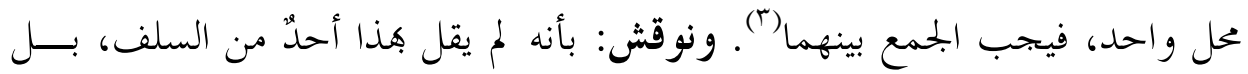

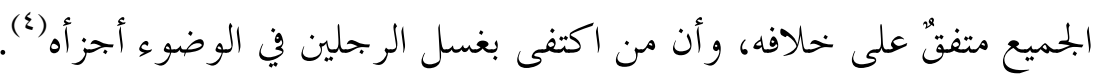

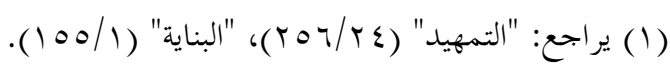

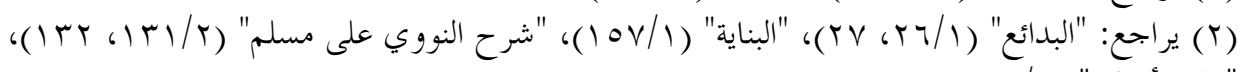

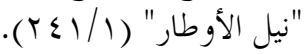

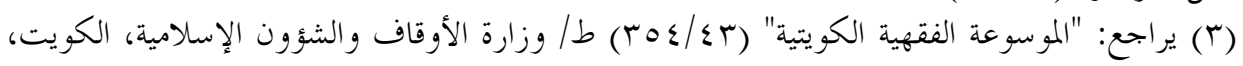




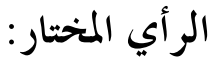

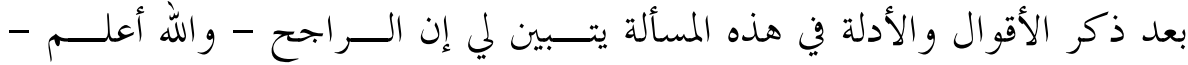
وجوب غسل القدمين، ولا يكفي في ذلك مسحهما، وحديث "ويل للأعقاب مــن

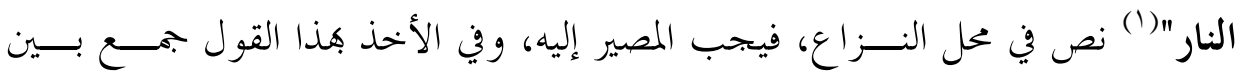

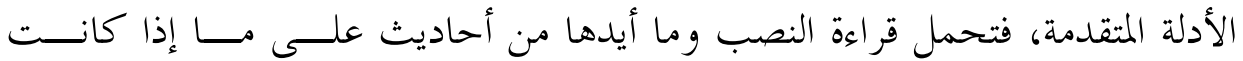

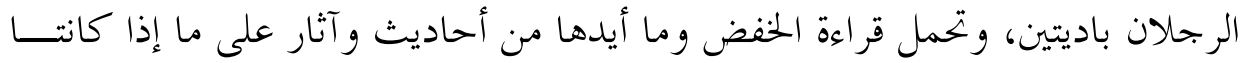

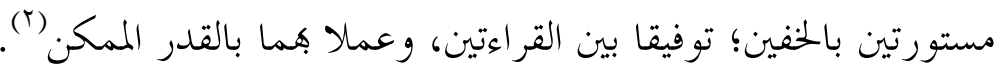

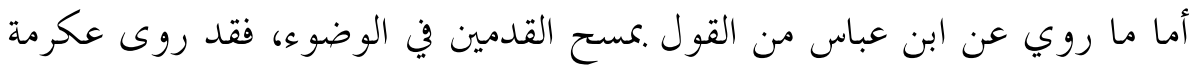

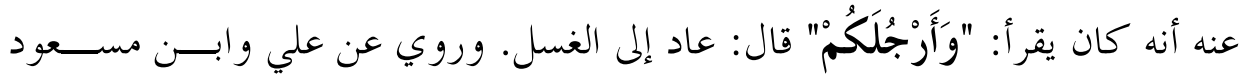
أهنم كانوا يقرؤوها كذلك (ب).

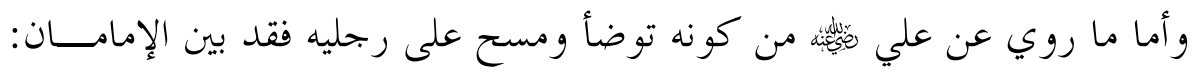

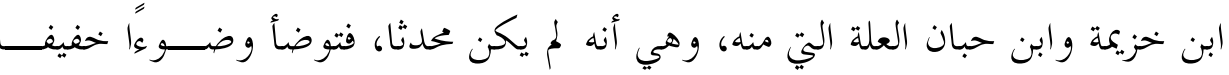

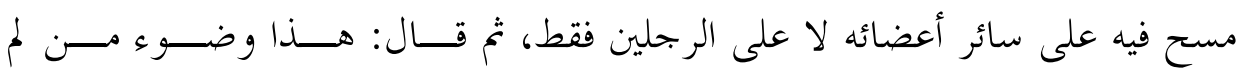

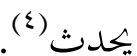

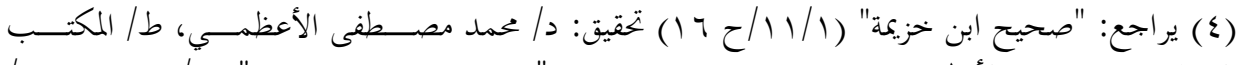

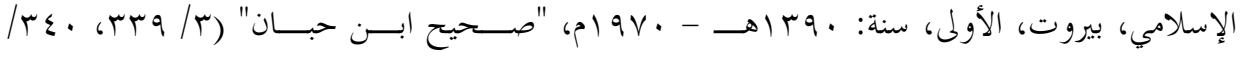
. (1.0V 
رأي ابن حبان الفقهي في فرض الرجلين في الوضوء

\section{الخخاتمت}

الحمد لله أو لا وأخرا وظاهرا وباطنا ونشهد أن لا إله إلا الله وحده لاشريك له

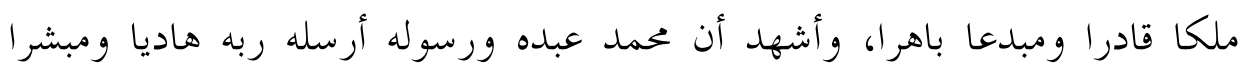
و نذيرا وداعيا إلي الله بإذنه وسر اجا منيرا.

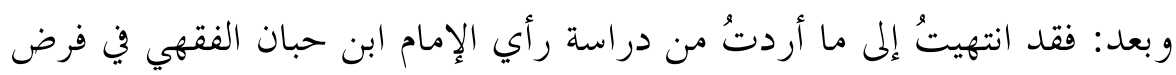

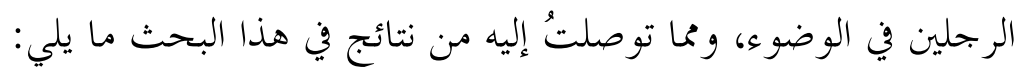

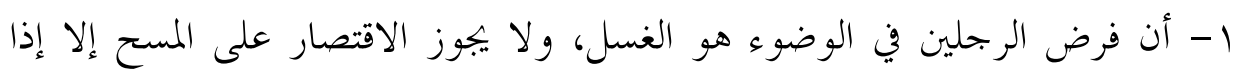
كان لابسا لخفيه، فيجوز حينئذ المسح على الحفين.

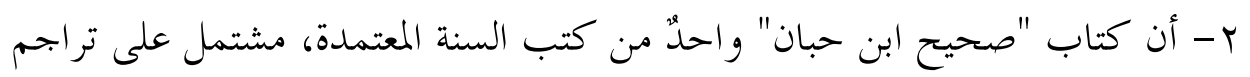
فقهية بتعله في عداد كتب الفقه إضافة إلى كونه كتاب حديث. r- ومما توصلت إليه في هذا البحث من نتائج المكانة العلمية الكبيرة للإمام بن حبان، وهذا واضح غاية الوضوح من طريقته في الاستباط وفهمه العميق لأحاديث النبي

\section{.

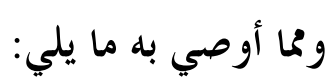

1- أوصي نفسي وإخواني من طلبة العلم أن يشمروا لها عن ساعد الجحد ويكشفوا عن ساق الاجتهاد رغبة في تحصيل فوائد هذا الكتاب الجليلة، وينقبو اعن عن نكاته الفقهية اللطيفة من خلال دراسة بقية أبواب هذا الكتاب. r- كما أوصي بعمل دراسة للمسائل التي انفرد بها ابن حبان و وحالف فيها جمهور الفقهاء، فهي فروع كثيرة تكفي لبحث كبير يظهر فيه كاتبه شخصية الإمام ابن 
حبان الفقهية وطريقته في الاستنباط.

وأسأل الله - جل علا - وهو خير مسئول أن يرزقي في هذا العمل الإخلاص ويمن علي بالقبول، والحمد الله رب العالمين، وصلي الله وسلم وبارك علي سيدنا محمد وعلي آله وصحبه و سلم.

*** 
رأي ابن حبان الفقهي في فرض الرجلين في الوضوء

\section{مراجع البحث}

$$
\begin{aligned}
& \text { القر آن الكريم. }
\end{aligned}
$$

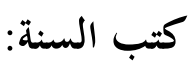

$$
\begin{aligned}
& 1 \text { - صحيح البخاري. ب- صحيح مسلم. } \\
& \text { r- صحيح ابن حبان. ع ع- سنن أبي داود. }
\end{aligned}
$$

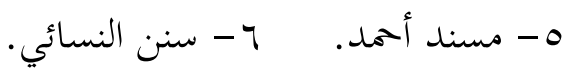

$$
\begin{aligned}
& \text { V- سنن الدار قطني. ی- المستدرك للحاكم. } \\
& 9 \text { - صحيح ابن خزيمة. • ا- سنن البيهقي. }
\end{aligned}
$$

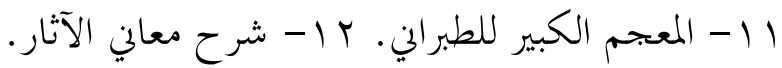

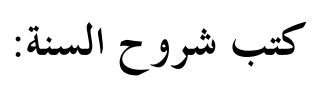

$$
\begin{aligned}
& 1 \text { - المفهم للقرطبي. ب- شرح النووي على مسلم. } \\
& \text { r- فتح الباري لابن حجر . ع - نيل الأوطار. }
\end{aligned}
$$

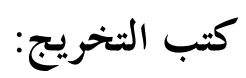

$$
\begin{aligned}
& \text { 1- مغني ذوي الأفهام لابن عبد الهادي. } \\
& \text { ץ- تنقيح التحقيق لابن عبد الهادي. } \\
& \text { كتب الفقه الحنفي: } \\
& 1 \text { - المبسوط للسرخسي. ب- بدائع الصنائع. } \\
& \text { r- البناية شرح الهداية. ع - بحمع البحرين. } \\
& \text { ه- - بحمع الأفر . }
\end{aligned}
$$




$$
\begin{aligned}
& \text { 1- الإشراف على نكت مسائل الخلاف. ب- ب- التلقين. } \\
& \text { r- المعونة. للقاضي عبد الوهاب. ع - الاستذكار. } \\
& \text { ه- بداية المجتهد. }
\end{aligned}
$$

1- الخلاصة للغزالي. ب - الحاوي للماوردي.

ب- البحموع للنووي. ع - البيان للعمراني.

0- متح العزيز للر افعي.

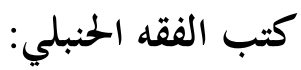

1- المغني لابن قدامة. r- العدة لبهاء الدين المقدسي.

r- الإقناع للحجاوي.

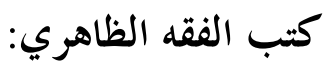

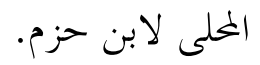

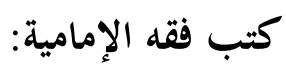

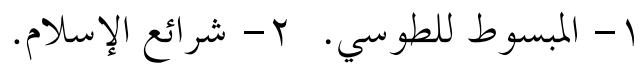

r- تحرير الأحكام للحلي.

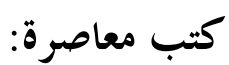

الموسوعة الفقهية الكويتية. 